УДК 681.54: 658.562.3

DOI https://doi.org/10.32838/TNU-2663-5941/2020.6-1/19

\title{
Маринич I.A.
}

Криворізький національний університет

Рубан С.A.

Криворізький національний університет

Сердюк О.Ю.

Криворізький національний університет

\section{СИНТЕЗ СИСТЕМИ УЗГОДЖЕНОГО КЕРУВАННЯ ДОЗУВАННЯ ВСІХ КОМПОНЕНТІВ ШИХТИ 3 ПАРАЛЕЛЬНИМ З'ЄДНАННЯМ ДОЗАТОРІВ}

У статті розглядається синтез системи автоматичного керування дозаторами компонентів иихти, що забезпечує мінімізачію відхилення співвідношення витрат компонентів від заданого значення. У роботі пропонується застосування як узгодженого керування окремими груповими дозаторами аглоруди, вапняку та коксу, так і системи керування груповим дозатором концентрату загалом на основі окремих моделей із контролем дозування відповідних компонентів шихти. Практична значимість полягає у застосуванні отриманих математичних розрахунків заданих значень витрат компонентів аглошихти й у можливості використання розробленої моделі у моделюванні технологічного процесу дозуванням компонентів шихти з заданими показниками якості роботи як окремого дозатору, так і роботи системи автоматичного дозування загалом.

На вітчизняних фабриках огрудкування найчастіше використовують системи автоматичного дозування компонентів иихти зі з'єднанням індивідуальних дозаторів. Для дозування аглоруди, вапняку і коксу використовуються стрічкові дозатори.Кожний стрічковий дозатор має власну систему управління продуктивністю, щцо складається з індивідуального вимірювача ваги, на основі якого в системі реалізовано зворотній зв'язок за продуктивністю дозатора. Дозування концентрату здійснюється груповим дозатором, що складається з дискових живильників, розміщених під бункерами концентрату, які вивантажують концентрат на збірний конвеєр. На основі математичних моделей елементів системи дозування розроблено структуру та визначено параметри налаштувань регуляторів для системи автоматичного дозування компонентів агломераційної шихти, що забезпечують високі якісні показники керування процесом. Синтезована система автоматичного дозування компонентів шихти за умов аглофабрики забезпечує мінімізаиію середньоквадратичного відхилення співвідношення витрат компонентів. Тривалість перехідного процесу за співвідношеннями витрат компонентів $і$ за загальною витратою становить близько 60 с. Система має невелике транспортне запізнення (близько 10 с), пов'язане з часом переміщення концентрату від конвеєрних вагів до кінщя стрічки.

Ключові слова: автоматизачія, груповий дозатор, дозування, моделювання, система автоматичного дозування, иихта.

Постановка проблеми. Дільниця дозування компонентів шихти фабрики огрудкування призначена для приготування суміші із концентрату, вапняку та бентоніту, іiі подальшого змішування та транспортування до дільниці огрудкування. Для забезпечення високих показників якості агломерату необхідно стабілізувати задане процентне співвідношення компонентів шихти. Оскільки в технологічному процесі дозування беруть участь 4-5 дискових дозаторів концентрату, 2 дискові дозатори аглоруди, по 2 стрічкові дозатори вапняку та коксу на одну лінію, з метою мінімізації відхилення співвідношення віддозованих матеріалів потрібно забезпечити ефективне керування всім комплексом технологічного обладнання. Цього можна досягти шляхом узгодженого керування дозуванням усіх шихтових матеріалів.

Аналіз останніх досліджень i публікацій. Питанню автоматизації процесів дозування, транспортування та змішування шихтових матеріалів на фабриках огрудкування присвячені роботи М.М. Бережного, Ю.Г. Гончарова, О.В. Дрімбо, А.Д. Іщенка, С.В. Мошенського, Е.А. Ісаєва та ін. Аналіз досліджень і публікацій показує, що сьогодні використовуються різні схеми реалізації систем дозування шихтових матеріалів. На вітчизняних фабриках огрудкування найчастіше використовують системи автоматичного дозування компонентів 
шихти зі з'єднанням індивідуальних дозаторів. Для дозування аглоруди, вапняку і коксу використовуються стрічкові дозатори. Кожний стрічковий дозатор має власну систему управління продуктивністю, що складається з індивідуального вимірювача ваги, на основі якого в системі реалізовано зворотний зв'язок за продуктивністю дозатора. Дозування концентрату здійснюється груповим дозатором, що складається 3 дискових живильників, розміщених під бункерами концентрату, які вивантажують концентрат на збірний конвеєр. Реалізація зворотного зв'язку за продуктивністю концентрату забезпечується за рахунок контролю загальної продуктивності конвеєрними вагами, розташованими за останнім дисковим дозатором.

Проаналізовані у роботах структури систем автоматичного дозування дозволяють зробити висновок про доцільність використання системи автоматичного дозування компонентів шихти 3 паралельним з'єднанням дозаторів. Завданнями системи $€$ забезпечення заданої продуктивності відділення дозування; стабілізація вмісту заліза в шихті шляхом керування витратою аглоруди залежно від витрати концентрату; стабілізація основності шихти шляхом керування витратою вапняку та коксу залежно від витрати рудної частини шихти. Для дозування концентрату доцільно використовувати груповий дозатор на основі дискових живильників [4]. Для дозування аглоруди, вапняку та коксу доцільно використовувати системи на основі індивідуальних дозаторів зі зворотним зв'язком за продуктивністю [2].

Виконане у роботах дослідження математичних моделей окремих елементів систем дозу- вання та критеріїв роботи систем автоматичного дозування показало, що для оцінки якості роботи окремого дозатору доцільно використати значення середньоквадратичного відхилення продуктивності. Як критерій оцінки якості роботи системи автоматичного дозування загалом найдоцільніше використати значення середньоквадратичного відхилення коефіцієнту співвідношення витрат компонентів $[1 ; 3]$.

Постановка завдання. У роботі необхідно виконати синтез системи автоматичного керування окремими дозаторами аглоруди, вапняку та коксу, системи керування груповим дозатором концентрату, і на основі окремих моделей розробити та промоделювати систему узгодженого керування дозуванням всіх компонентів шихти. Визначити критерії для оцінки якості керування як окремим дозатором, так і системи загалом.

Виклад основного матеріалу досліджень. Аналіз технологічного процесу дозування компонентів шихти на прикладі агломераційної фабрики ГЗК показує, що найдоцільнішим $є$ використання системи автоматичного дозування компонентів шихти 3 паралельним з'єднанням дозаторів (рис. 1) [5].

Завдання загальної продуктивності за шихтою надходить із системи узгодження продуктивності спікального відділення та відділення підготовки шихти. Далі на основі алгоритму розрахунку складу агломераційної шихти визначаються коефіцієнти вмісту компонентів $\left(K_{\kappa}, K_{a 2}, K_{6}, K_{\text {кокс }}\right)$ в агломераційній шихті та в елементах множення

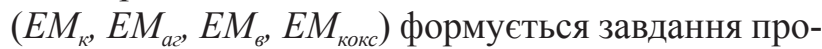
дуктивності для групових дозаторів концентрату, аглоруди, вапняку та коксу.

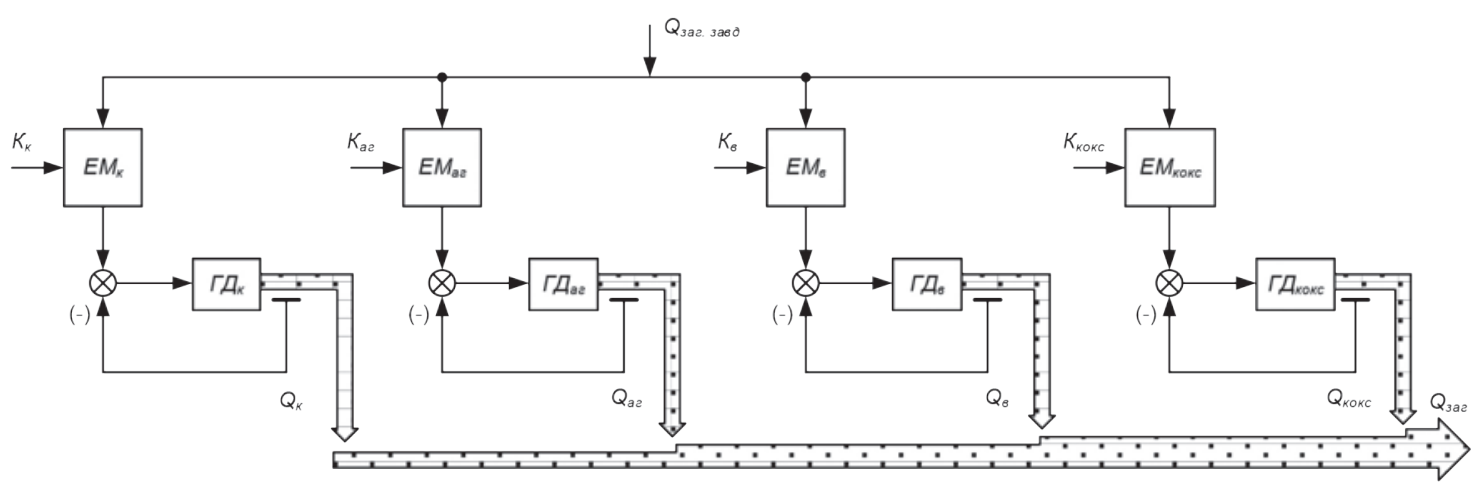

Рис. 1. Структурна схема паралельного з'сднання дозаторів:

ГД, Г Га а $\mathrm{EM}_{\text {кокс }}$ - елементи множення для розрахунку заданої витрати концентрату, аглоруди, вапняку та коксу відповідно; $\mathrm{Q}_{\text {зағзавд }}$ - задана загальна продуктивність системи дозування шихтових матеріалів; $\mathrm{K}_{\mathrm{k}}, \mathrm{K}_{\mathrm{ar}}, \mathrm{K}_{\mathrm{B}}, \mathrm{K}_{\text {кокс }}$ - розраховані коефіцієнти вмісту концентрату, аглоруди, вапняку та коксу в агломераційній шихті; $\mathrm{Q}_{\text {заг }}$ - фактична продуктивність системи дозування; $\mathrm{Q}_{\kappa}, \mathrm{Q}_{\mathrm{ar}}, \mathrm{Q}_{\mathrm{B}}, \mathrm{Q}_{\text {кокс }}$ - фактичні витрати концентрату, аглоруди, вапняку та коксу відповідно 
Дозування концентрату доцільно здійснювати груповим дозатором, що складається 3 декількох дискових живильників, розміщених під відповідними бункерами концентрату, а для дозування вапняку - використовувати стрічкові дозатори, які розвантажують бункери вапняку. Кожний стрічковий дозатор має власну систему керування продуктивністю, що складається з регулятора на базі ПЛК та індивідуального вимірювача ваги, на основі якого в системі реалізовано зворотній зв'язок за продуктивністю дозатора. Регулювання витрати вапняку здійснюється шляхом змінення швидкості руху стрічкового конвеєра. Для дозування коксу доцільно використати груповий дозатор, що складається зі стрічкових дозаторів, які розвантажують бункери коксу. Регулювання витрати коксу здійснюється шляхом змінення частоти обертання двигуну віброприводу дозатора.

Якість роботи систем автоматичного дозування залежить, з одного боку, від точності дозаторів і структури систем, а з іншого - від характеру і величини збурюючих впливів. Збурюючі впливи в системах дозування викликані цілим рядом причин i мають різний характер. Поряд із різкими короткочасними збуреннями (наприклад, внаслідок обрушення матеріалу в бункері), на системи діють і більш плавні впливи, які викликаються, наприклад, зміненням рівня матеріалу в бункері, зміненням насипної маси матеріалу і т. д. [6; 7].

Підвищення точності дозування забезпечується правильним вибором верхніх меж продуктивності живильників і вимірювачів ваги, а також вибором оптимальних налаштувань регулятора. Максимальні значення продуктивності елементів систем дозування повинні відрізнятися не більш ніж на 15-20\% від фактичних максимальних значень витрат матеріалів. Налаштування регулятора доцільно приймати такими, щоб забезпечувався коливальний характер процесу дозування [7].

Критерієм якості роботи систем автоматичного дозування є стабільність коефіцієнтів співвідношення витрат матеріалів, що дозуються.

Для оцінки якості роботи систем автоматичного дозування використовуються такі основні критерії [4; 9]:

1. Відхилення коефіцієнта співвідношення віддозованих мас компонентів від заданого значення

$$
\Delta K_{c}=K_{c .3}-\frac{\int_{0}^{t_{K}} Q_{\sigma} \cdot d t}{\int_{0}^{t_{K}} Q_{a} \cdot d t} \leq \Delta K_{c . n p u n},
$$

де $K_{c .3}$ - задане значення коефіцієнта співвідношення мас компонентів; $\Delta K_{c . n p u n}-$ припустиме значення відхилення коефіцієнта співвідношення віддозованих мас компонентів від заданого значення; $Q_{a}, Q_{\sigma}$ - витрати першого та другого компонентів відповідно.

2. Середньоквадратичне відхилення коефіцієнту співвідношення витрат компонентів

$$
\sigma_{K i}=\sqrt{\frac{\sum_{i=1}^{n}\left(K_{c i}-K_{c . c e p}^{\prime}\right)^{2}}{n}-\frac{\sum_{i=1}^{n}\left(K_{c}-K_{c . c e p}^{\prime}\right)^{2}}{n}},
$$

де $K_{c i}$ - поточне значення коефіцієнта співвідношення мас; $K_{c}$ - середнє за час $t_{K}=n \cdot \Delta t$ значення коефіцієнта співвідношення мас; $K_{\text {c.сер }}^{\prime}$ - середнє за тривалий проміжок часу (декілька годин, діб) значення коефіцієнта співвідношення мас.

Отже, для системи автоматичного керування процесом дозування для оцінки якості роботи окремого дозатору доцільно використати значення середньоквадратичного відхилення продуктивності. Як критерій оцінки якості роботи системи автоматичного дозування загалом найдоцільніше використати значення середньоквадратичного

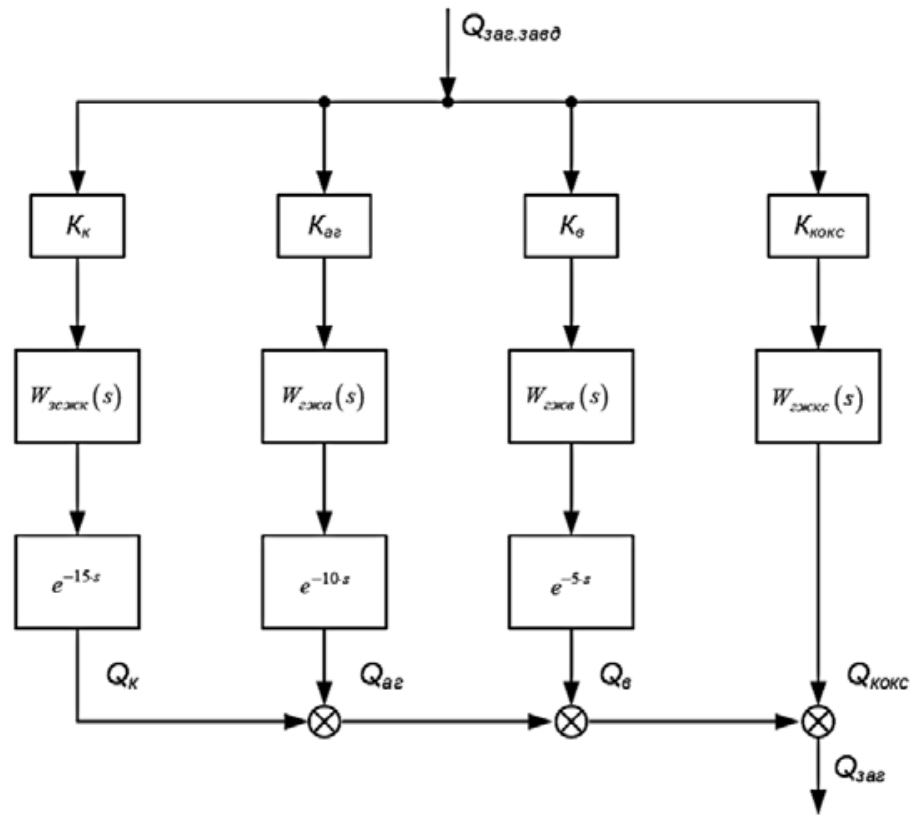

Рис. 2. Структурна схема системи автоматичного дозування компонентів шихти 
відхилення коефіцієнту співвідношення витрат компонентів.

Структурну схему системи автоматичного керування дозуванням 3 урахуванням транспортних запізнень, пов'язаних із транспортуванням компонентів, можна зобразити у вигляді, наведеному на рис. 2 [8].

На структурній схемі позначені передаточні функції: $W_{\text {зсжк }}(s)$ - передаточна функція САК груповим дозатором концентрату, $W_{\text {гжка }}(s), W_{\text {зсжк }}(s)$, $W_{\text {зсжкс }}(s)$ - передаточні функції групових дозаторів аглоруди, вапняку та коксу відповідно.

Після корекції системи керування продуктивністю окремого стрічкового дозатора й апроксимації передаточних функцій групових дозаторів вапняку, коксу й аглоруди можна синтезувати систему автоматичного керування дозуванням шихти 3 узгодженим керуванням окремими компонентами.

Модель синтезованої системи автоматичного дозування компонентів шихти, яка відповідає структурі, наведеній на рис. 2, реалізована у середовищі MatLab/Simulinc, представлена на рис. 3.

У моделі блоку «Grup dozator koncentrata» відповідає модель групового дозатору концентрату, блоку «Grup dozator aglorudy» - модель групового дозатору аглоруди, блоку «Grup dozator vapnyaka» - модель групового дозатору вапняку та блоку «Grup dozator koksu» - модель групового дозатору коксу. Блоки «Transport Delay», «Transport Delay 1» і «Transport Delay 2» моделюють час переміщення матеріалу від місць розвантаження відповідних матеріалів (концентрату, аглоруди, вапняку) на збірний конвеєр до конвеєрних вагів.

Для оцінки якості системи автоматичного дозування компонентів шихти доцільно проаналізувати графіки перехідних процесів коефіцієнтів співвідношення між матеріалами, що дозуються [12]. Так, на рис. 4 наведено графік перехідного процесу співвідношення між витратою концентрату й аглоруди:

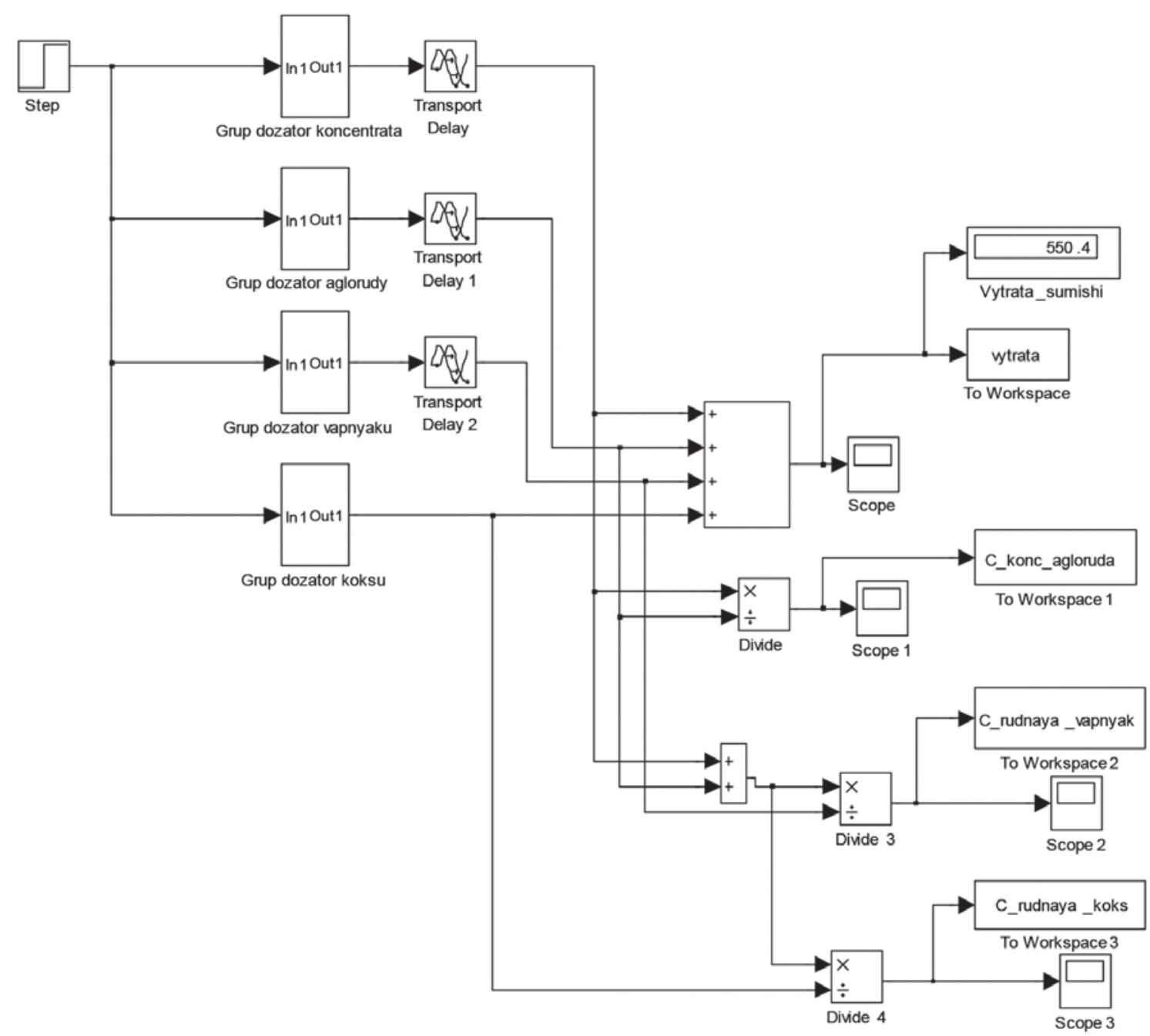

Рис. 3. Модель системи автоматичного дозування компонентів шихти 


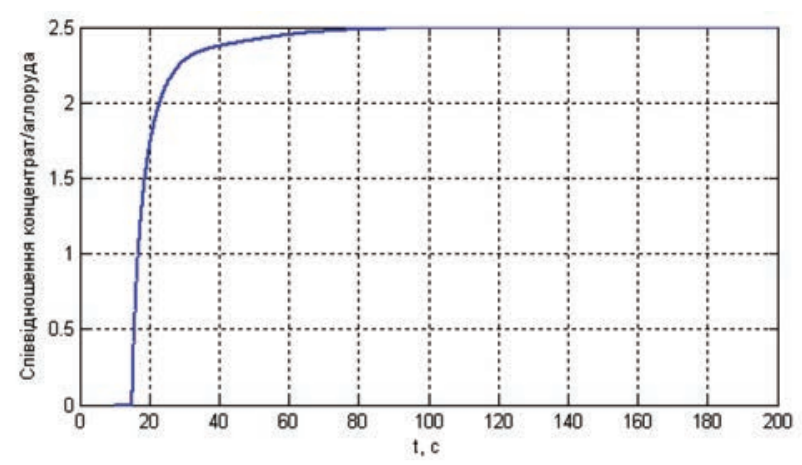

Рис. 4. Графік перехідного процесу співвідношення між витратою концентрату й аглоруди

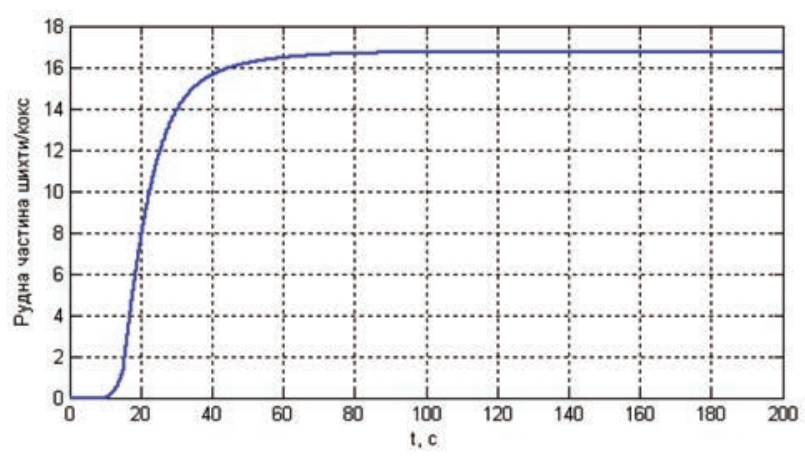

Рис. 6. Графік перехідного процесу співвідношення між витратою рудної частини шихти та коксом

на рис. 5 - між витратою рудної частини шихти (концентрат + аглоруда) та вапняку, на рис. 6 - між витратою рудної частини шихти та коксом.

Графік перехідного процесу за витратою всіх компонентів суміші (концентрат, аглоруда, вапняк, кокс) у синтезованій системі автоматичного дозування компонентів шихти для умов аглофабрики наведено на рис. 7.

Висновки. Аналіз наведених на рис. 4-7 графіків свідчить, що синтезована система автоматичного дозування компонентів шихти за умов аглофабрики забезпечує мінімізацію середньоквадратичного відхилення співвідношення витрат компонентів. Система відпрацьовує задане співвідношення між витратою компонентів: концентрату й аглоруди

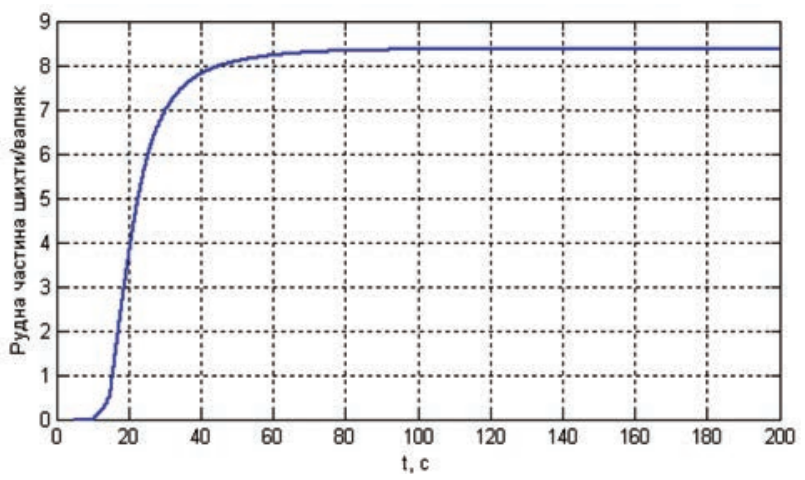

Рис. 5. Графік перехідного процесу співвідношення між витратою рудної частини шихти та вапняком

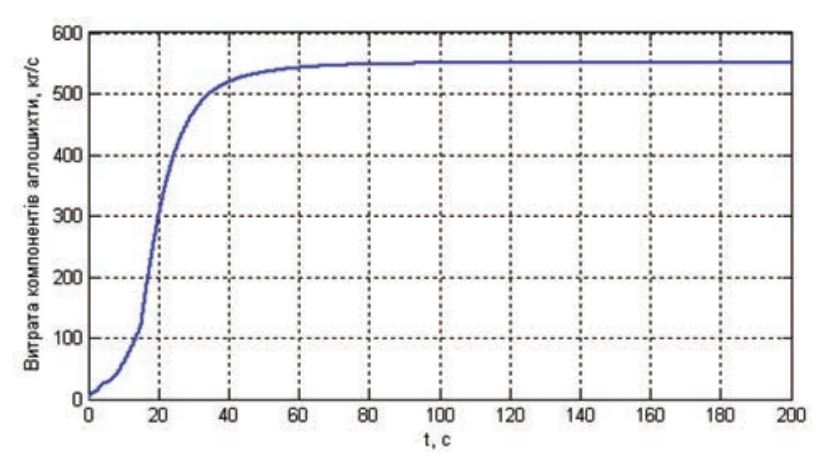

Рис. 7. Графік перехідного процесу за витратою компонентів агломераційної шихти

(2,5:1), рудної частини шихти та вапняку $(8,4: 1)$, рудної частини шихти та коксу $(16,7: 1)$.

Тривалість перехідного процесу за співвідношеннями витрат компонентів і за загальною витратою становить близько 60 с. Система має невелике транспортне запізнення (близько 10 с), пов'язане $з$ часом переміщення концентрату від конвеєрних вагів до кінця стрічки. Отже, на основі виконаного комп'ютерного моделювання можна зробити висновок, що розроблена система відповідає всім вимогам і може використовуватися для моделювання технологічного процесу дозування компонентів шихти із заданими показниками якості роботи як окремого дозатору, так і роботи системи автоматичного дозування загалом.

\section{Список літератури:}

1. Ульшин В.А., Гавриш А.И., Кобец Д.В. Оптимальное управление производительностью автодозаторов на УОФ. Вісн. Східноукр. нач. ун-ту ім. В. Даля. 2007. № 12 (118). С. 232-236.

2. Спосіб дозування агломераційної шихти. Нечитайло В.М. та ін. Деклараційний патент України на корисну модель № 7785, 2005, Бюл. № 7.

3. Гудима В.И. Основы автоматизации обогатительных фабрик. Харків : Хорознь, 2001, 480 с.

4. Федоровский Н.В., Даньшин В.В., Губанов В.И., Сигуа Р.И. Автоматизация фабрик окускования железных руд и концентратов. Москва : Металлургия, 1986. 208 с.

5. Гончаров Ю.Г., Дримбо А.В., Ищенко А.Д. Автоматизация процессов окускования железных руд. Москва : Металлургия, 1983. 192 с. 


\section{Marynych I.A., Ruban S.A., Serdiuk O.Yu. SYNTHESIS OF COORDINATED CONTROL SYSTEM FOR DOSING OF ALL CHARGE COMPONENTS WITH PARALLEL CONNECTION OF DOSING DEVICES}

Article discusses synthesis of system of charge components batchers automatic control, which ensures minimization of deviation of component cost ratio from specified value. Work proposes use of coordinated control of both individual group dosers of aglore, limestone and coke, and control system of group doser of concentrate as whole based on separate models with control of dosing of corresponding components of charge. Practical significance lies in application of obtained mathematical calculations of given cost values of agglomeration components and in possibility of using developed model when modeling technological process by dosing charge components with given performance indicators, both separate dispenser and operation of automatic dosing system as whole.

In domestic shrouding factories, most often systems for automatic dosing of charge components with connection of individual dispensers are used. Tape dispensers are used for dosing sinter ore, limestone and coke. Each belt dispenser has its own performance control system, consisting of individual weight meter, on basis of which system provides feedback on dispenser performance. Concentrate is dosed by group dispenser consisting of disk feeders located under the concentrate hoppers, which discharge concentrate to assembly conveyor. On basis of mathematical models of dosing system elements, structure was developed and settings of regulators for system of automatic dosing of agglomeration charge components were determined, providing high qualitative process control indicators. Synthesized system of automatic dosing of charge components under conditions of agglomeration ensures minimization of standard deviation of components consumption ratio. Duration of transition process according to component flow ratios and the total flow is about $60 \mathrm{~s}$. System has small transport lag (about 10 seconds) associated with travel time of concentrate from weighing conveyor to end of belt.

Key words: automation, group dosing unit, dosing, modeling, automatic dosing system, charge. 